\title{
Mainstreaming ecosystem services in state-level conservation planning: progress and future needs
}

\author{
Ryan R. Noe ${ }^{1}$, Bonnie L. Keeler ${ }^{1}$, Michael A. Kilgore $^{2}$, Steven J. Taff $^{3}$ and Stephen Polasky ${ }^{4}$
}

\begin{abstract}
Ecosystem services (ES) have become an important focus of the conservation movement but have yet to be mainstreamed into environmental policy and management, especially at the state and federal levels. Adoption of an ES approach requires agency personnel to have knowledge or experience in implementing an ES approach and metrics that link potential actions to impacts on ES. We characterize the degree to which ES considerations are taken into account in setting priorities for conservation acquisitions in the U.S. state of Minnesota. We assess two core dimensions of an ES approach: (1) multiobjective targeting and (2) measuring program benefits in terms of increases in human well-being. We assess the degree to which these two dimensions occur in statute and in conservation program decision making. We find that state statute provides clear support for an ES approach in conservation funding mechanisms. However, we find that many of the programs funded through those mechanisms have more traditional habitat-centric approaches. In contrast to statutory emphasis, water quality related metrics were not prominent. We recommend expanding current prioritization systems to include a broader suite of metrics that are linked to human well-being to further mainstream ES in Minnesota. These metrics can be generated from existing data and would allow program managers to better communicate the public benefits of conservation spending.
\end{abstract}

Key Words: easements; habitat; metrics; policy; water quality

\section{INTRODUCTION}

\section{Need for an ecosystem services based approach}

There is growing interest by public and private sector decision makers in adopting an ecosystem services (ES) approach to landscape management, including how they allocate funding, plan future investments, and evaluate the potential benefits and costs of proposed projects (Daily et al. 2009, Guerry et al. 2015, Schaefer et al. 2015). In 2015, the U.S. Office of Management and Budget issued a memorandum directing U.S. federal agencies, "to develop and institutionalize policies to promote consideration of ecosystem services, where appropriate and practicable, in planning, investments, and regulatory contexts" (Donovan et al. 2015:1). Governments in other countries such as China, Costa Rica, and the U.K. have also adopted ecosystem services-oriented national policies (Liu et al. 2008, Pagiola 2008, UK NEA 2014, Ouyang et al. 2016). Internationally, more than 100 countries have signed on to the Intergovernmental Platform on Biodiversity and Ecosystem Services (IPBES) and the World Bank has sponsored work to incorporate ecosystem services in national income accounting (Wealth Accounting and Valuation of Ecosystem Services). The private sector has also shown interest in adopting ecosystem services and natural capital accounting frameworks to guide decisions about procurement, manage risk, and to pursue more sustainable business or sourcing strategies (TEEB 2010, Kupers et al. 2015).

An ES approach differs from a business as usual approach to land management because of its emphasis on the multiple benefits landscapes provide, inclusive of both private benefits (e.g., agricultural production or timber revenue) and public benefits (e. g., clean water or clean air). An ES approach explicitly considers human well-being as a desired endpoint of land and water management (MEA 2005). Ecosystem services assessments go beyond biological or chemical endpoints (e.g., habitat quality or units of pollution) to include metrics of human well-being (e.g., health, recreation, property values). Adopting a definition of "final ecosystem services," we assume an ES approach requires an analysis framework that links actions or interventions directly or indirectly to some aspect of human well-being (Boyd and Banzhaf 2007, Landers and Nahlik 2013).

Despite broad interest in an ES approach, several studies have highlighted the challenges of implementing ES in existing conservation activities (Sitas et al. 2014, Presnall et al. 2015, Galler et al. 2016). Implementation of an ES approach requires agencies and land managers to have both the statutory authority and the capacity to perform the analyses. However, in a survey of over 500 U.S. Forest Service employees, Presnall et al. (2015) found that even when there was guidance encouraging the use of an ES approach, practitioners often felt explicit directives or legal requirements were necessary before incorporating ES into their analyses. Even with strong statutory support, such as that which is found in South Africa's Constitution, a case study in the region found that confusion from stakeholders on the concept of ES, limited capacity to perform new analyses, incentive mismatches, and conflicting policies hinder management of landscapes for ecosystem services and multiple benefits (Sitas et al. 2014). Quantifying the impact of conservation on the delivery of multiple ecosystem services requires diverse expertise and social and biophysical data collection, posing challenges for managers that are traditionally focused on species conservation and habitat protection.

Uptake of ES approaches in U.S. land management will require both policy makers and land managers to update their approaches

${ }^{1}$ Institute on the Environment, University of Minnesota, ${ }^{2}$ Department of Forest Resources, College of Food Agricultural and Natural Resource Sciences, University of Minnesota, ${ }^{3}$ Department of Applied Economics, University of Minnesota, ${ }^{4}$ Department of Applied Economics, Department of Ecology, Evolution, and Behavior, and Institute on the Environment, University of Minnesota 
and tools to include new guidance, data sources, metrics, and models. To inform this effort, we set out to characterize the conservation acquisitions process in one U.S. state, including both the guidance in the enabling statute of funding mechanisms and agency programs, and the metrics used to make decisions. With this information, we can assess the extent to which an ES approach is used and identify specific areas that policy guidance or practitioner's tools may need to shift to more fully account for the value of investments in conservation. In doing so, we address a global need to identify and address barriers to adoption of ES approaches in conservation policy, planning, and land acquisition.

\section{Using conservation acquisitions in Minnesota, USA as a case study}

Minnesota has devoted significant public resources to conservation, most recently through adoption of the Clean Water, Land and Legacy constitutional amendment that dedicates revenue from a 25-year sales tax increase to fund investments in the environment and the arts (Minn. Const. art. XI sec. 15; ORS 2008). Since its passage in 2008, the Legacy Amendment has generated an average of US\$221 million each year for environment-focused funds (LCC 2016a). Furthermore, a 1998 constitutional amendment designated proceeds from the state lottery to an Environment and Natural Resources Trust Fund. Between 2010 and 2016 this fund provided an average of US\$30 million annually for, "the public purpose of protection, conservation, preservation, and enhancement of the state's air, water, land, fish, wildlife, and other natural resources" (Minn. Const. art. XI sec. 14; ORS 1998, LCC 2016b). Even with higher than average state funding devoted to conservation, demand for these resources outpaces supply, forcing conservation organizations and agencies to look for ways to make the most efficient use of limited public funds.

We assessed the extent to which state policies, metrics, and programs receiving funds under these programs align with an ES approach as defined above. We focused on conservation programs that acquire either conservation easements or land in fee-title. In fee-title acquisition, the buyer purchases all rights associated with a parcel, whereas conservation easements transfer only some the rights. Often, a conservation easement precludes development or agriculture but allows the owner to retain exclusive access to the parcel. As a result, easements are typically less expensive than feetitle acquisition, but public access for activities such as hunting or fishing must be negotiated on a case-by-case basis.

We examined the enabling statutes of funds and programs as well as the techniques organizations use to prioritize acquisitions with the goal of identifying opportunities to mainstream ES within existing statutes and programs. We aimed to address the following three research questions in our assessment:

1. Do Minnesota statutes enable the adoption of an ecosystem services approach?

2. What metrics or priorities do organizations using public funds for conservation acquisitions currently employ?

3. Do the metrics and weights used by conservation organizations reflect the conservation and human well-being priorities described in statutes and are they consistent with an ecosystem services approach?

\section{METHODS}

\section{Identifying ecosystem services principles in statute}

We performed document review on two sets of documents relevant to conservation acquisitions in Minnesota: (1) the scoring systems created by conservation programs to prioritize acquisitions specific to their mission, and (2) the Minnesota statute that created each conservation program or fund.

To allow for consistent comparisons of the weight assigned to metrics, we limited our analysis to programs that use quantitative prioritization scoring systems, as well as the state funds that contribute to these programs. We included nine programs, six operated by the Minnesota Department of Natural Resources (DNR) and three by the Minnesota Board of Water and Soil Resources (BWSR). The DNR and BWSR make up the largest recipient of state funding for conservation easements, together receiving nearly a billion dollars between 2010 and 2016 from Legacy Amendment funds alone (LCC 2016a). We excluded six private conservation organizations because they did not use quantitative prioritization scoring systems.

We then reviewed the statute that created each program or fund for the presence of ecosystem service principles. Because the phrase "ecosystem services" is not yet common in legal contexts, we instead searched for references to the two primary components of an ES approach: reference to multiple benefits and reference to human beneficiaries (Appendix 1, Table A1.1). If the language explicitly called for multiple benefits or listed several broad categories of services, we considered it to meet the multiple benefits criterion. If the language explicitly mentioned humans (including related terms such as individuals, people, the public, citizens, residents, etc.) as the intended beneficiaries, we considered it to meet the human beneficiaries criterion.

\section{Quantifying acquisition prioritization metric weights}

We contacted all state agencies and conservation organizations in Minnesota that operate statewide conservation acquisition programs and receive public funding for easements or land acquisitions. We requested documentation of any quantitative scoring system that they use to prioritize acquisitions. To develop a consistent comparison of weights between programs that use disparate metrics, we aggregated individual metrics used in quantitative prioritization systems into 10 categories (Appendix 2). For example, the Wildlife Management Area (WMA) program awards points for parcels that have wetland complexes on them. We assigned the points from this metric to the category of habitat/ biodiversity under our system because the scoring guidance stressed the importance of wetland complexes for waterfowl breeding. To avoid double counting, we assigned each point of a metric to a single category only (Appendix 3). We divided the maximum score in a given category by the overall maximum score attainable under each program to determine the weight a program placed on a category. Further assumptions, described in the supporting information, were required to aggregate scores from the DNR's WMA and Aquatic Management Area (AMA) programs and BWSR's Wetland Restoration program (Appendix 2, Table A2.1 and A2.2, Appendix 3). Finally, we compared the specific benefits listed in the funding legislation to those prioritized under current metrics and approaches used by conservation organizations and agencies receiving funding. 
Table 1. Principles of ecosystem services and specific benefits called for in conservation program and conservation fund enabling statutes. The enabling statutes for programs reviewed broadly supported an ecosystem services-based approach even though the phrase "ecosystem services" was not used. The benefits called for in the statute were typically water quality, habitat, and recreation. The "Other" category includes flood mitigation, carbon storage, scenic services, timber production, and air and land quality. With the exception of DNR's Native Prairie Bank, the enabling statutes for all programs or funds called for multiple benefits.

\begin{tabular}{|c|c|c|c|c|c|c|c|}
\hline \multirow[t]{2}{*}{ Programs } & \multirow[t]{2}{*}{$\begin{array}{l}\text { Enabling } \\
\text { Statute }\end{array}$} & \multicolumn{2}{|c|}{$\begin{array}{l}\text { Principles of Ecosystem } \\
\text { Services in Statute }\end{array}$} & \multicolumn{4}{|c|}{ Benefits Called For in Statute } \\
\hline & & $\begin{array}{l}\text { Calls for } \\
\text { multiple } \\
\text { benefits }\end{array}$ & $\begin{array}{c}\text { Calls for } \\
\text { human } \\
\text { beneficiaries }\end{array}$ & $\begin{array}{l}\text { Water } \\
\text { quality }\end{array}$ & Habitat & Recreation & Other \\
\hline DNR Aquatic Management Areas & 86A.05 & Yes & Yes & $\mathrm{X}$ & $\mathrm{X}$ & $\mathrm{X}$ & \\
\hline DNR Wildlife Management Areas & 86A.05 & Yes & Yes & & $\mathrm{X}$ & $\mathrm{X}$ & \\
\hline DNR Trout Stream Easements & 84.0272 & Yes & Yes & & $\mathrm{X}$ & $\mathrm{X}$ & \\
\hline DNR Scientific and Natural Areas & 86A.05 & Yes & Yes & & $\mathrm{X}$ & $\mathrm{X}$ & \\
\hline DNR Native Prairie Bank & 84.96 & No & No & & $\mathrm{X}$ & & \\
\hline DNR Forests for the Future & 84.66 & Yes & Yes & $\mathrm{X}$ & $\mathrm{X}$ & $\mathrm{X}$ & $\mathrm{X}$ \\
\hline BWSR Wetland Restorations & 84.95 & Yes & No & $\mathrm{X}$ & $\mathrm{X}$ & & $\mathrm{X}$ \\
\hline BWSR Grassland Reserve & 84.95 & Yes & No & $\mathrm{X}$ & $\mathrm{X}$ & & $\mathrm{X}$ \\
\hline $\begin{array}{l}\text { BWSR Wildlife Riparian Buffers } \\
\text { Funds }\end{array}$ & 84.95 & Yes & No & $\mathrm{X}$ & $\mathrm{X}$ & & $\mathrm{X}$ \\
\hline Environment and Natural Resources Trust Fund & $116 \mathrm{P}$ & Yes & Yes & $\mathrm{X}$ & $\mathrm{X}$ & $\mathrm{X}$ & $\mathrm{X}$ \\
\hline Clean Water Fund & 114D & Yes & Yes & $\mathrm{X}$ & & $\mathrm{X}$ & \\
\hline Lessard-Sams Outdoor Heritage Fund & 97A.056 & Yes & Yes & & $\mathrm{X}$ & $\mathrm{X}$ & \\
\hline
\end{tabular}

\section{RESULTS}

Do Minnesota statutes enable an ecosystem services approach?

Review of Minnesota statutes showed that almost all legislation either directly called for multiple benefits or specifically listed several distinct benefits (Table 1). Mention of human beneficiaries was also common to all legislation except programs under the Reinvest in Minnesota Resources statute (RIM) and the Native Prairie Bank program. Though RIM did not have explicit references to human beneficiaries, its direction to prioritize protection of drinking water sources provided guidance specific to human well-being. Even programs that did not have elements of an ES approach in their enabling legislation are often funded by the Legacy Amendment and Environment and Natural Resources Trust Fund, both of which have support for an ES approach in their enabling legislation. We concluded that the legislation enabled and reinforced an ES approach, even though the words "ecosystem services" were not used.

The most commonly mentioned benefits called for in statutory language were water quality, recreation, and habitat quality (Table 1). All enabling statutes reviewed, except for the DNR's Native Prairie Bank program, called for at least two of these three benefits. Of the conservation programs, only RIM and the Forests for the Future program specifically mention benefits distinct from these areas. Reinvest in Minnesota Resources includes carbon storage and flood mitigation, whereas Forest for the Future calls for the consideration of timber production, air quality, carbon storage, and scenic services in addition to recreation, habitat, and water quality. Of the funding sources, the Environment and Natural Resources Trust Fund was the only one to explicitly go beyond water quality, recreation, and habitat quality, calling for air and land quality as well as a catchall for other natural resources.
What metrics or priorities do organizations using public funds for conservation acquisitions currently employ?

Habitat and biodiversity related metrics typically made up around half of the score of a program. When metrics closely related to habitat (i.e., habitat/biodiversity, size, and spatial context) are grouped together, they accounted for at least $75 \%$ of the total score in all of the programs reviewed except for DNR's Forests for the Future (Fig. 1). Water quality did not make up more than $5 \%$ of the total score of any program. Metrics that took into account the demand for and accessibility of recreation benefits (i.e., recreation accessibility) received between $6 \%$ and $17 \%$ of the total score and were not considered in four of the programs.

Several programs also considered variables related to the logistics of acquiring and managing the land, market benefits from timber or grazing, the willingness of the landowner to donate a portion of the land's value, public support for acquisition, and risk of development. These variables collectively accounted for 0 to $36 \%$ of a program's score, with a median of $10 \%$ (Fig. 1). Public support for acquisitions was considered only by the DNR Forests for the Future program, in which public support was measured by the presence of letters of support and landowner engagement. Risk of development was measured either through expert-opinion based knowledge of the local market or the presence of other restrictions on the parcel (Appendix 3).

Do the metrics and weights used by conservation organizations reflect the conservation and human well-being priorities described in statutes and are they consistent with an ecosystem services approach?

All of the conservation programs in our review included metrics of habitat quality in their scoring system, consistent with the statutory language calling for habitat benefits from conservation investments in all of the statutes reviewed, with the exception of the Clean Water Fund (Fig. 1; Table 1). For example, the WMA 
Fig. 1. Conservation programs and the weight ( $\%)$ they place on different metric categories when scoring potential acquisitions. Despite many programs and funds highlighting water quality and recreation as priorities, very little weight is placed on metrics related to water or the accessibility of acquisitions. The risk of development is also important for efficient spending by protecting benefits most likely to be lost, but is not heavily weighted by these programs.

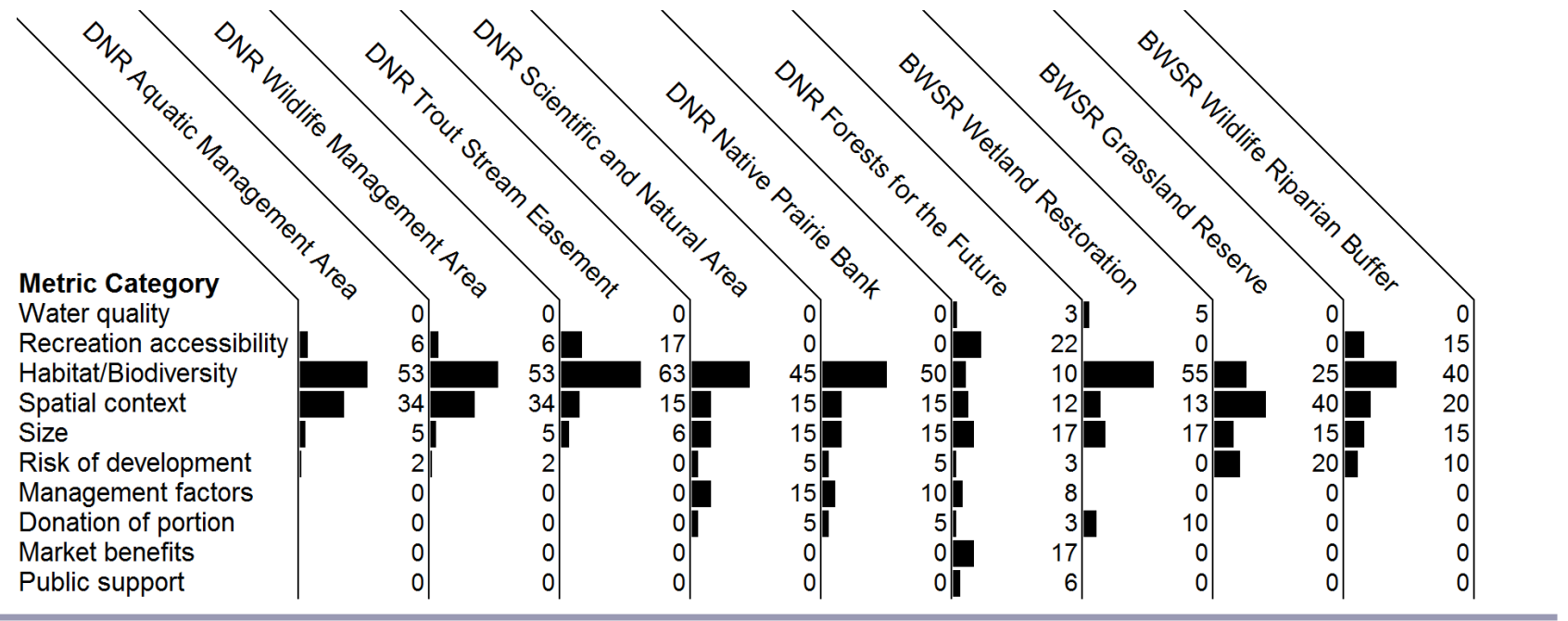

program statute states that wildlife management areas, "shall be established to protect those lands and waters which have a high potential for wildlife production and to develop and manage these lands and waters for the production of wildlife, for public hunting, fishing, and trapping, and for other compatible outdoor recreational uses" (Minnesota Statutes 2017 section 86A.05 subd. 8; ORS 2017). Consistent with this language, WMA scoring systems emphasized habitat quality over other potential ES benefits (Fig. 1). Habitat quality in and of itself is not an ecosystem service, but may be strongly linked to the final ES of recreation.

Although recreation benefits were called for in all of the conservation funds and all programs except for the DNR's Native Prairie Bank and BWSR's RIM, the metrics we reviewed lacked an emphasis on access, proximity to population centers, or the preferences or behavior of recreationists that would more directly link investments in habitat quality to improvements in hunting, angling, wildlife viewing, or other metrics of human well-being. Only the DNR WMA, AMA, and the Trout Stream Easement programs take into account the local population and demand, giving the category a weight of $6 \%, 6 \%$, and $17 \%$, respectively (Fig. 1).

Water quality was mentioned in statutory language authorizing two of the three funds and five of the nine programs reviewed (Table 1). The programs that did mention water quality as a goal include RIM and the Clean Water Fund, which are among the most well-funded of all the programs. Despite millions of dollars of funding dedicated to water quality and frequent mention as a priority in statutes, water quality metrics were missing from all but two of the scoring systems used to prioritize conservation acquisitions. The BWSR's Wetland Restoration and DNR's Forests for the Future programs weighted water quality at $5 \%$ and $3 \%$ (Fig. 1).

\section{DISCUSSION}

Mainstreaming an ES approach that prioritizes managing for multiple benefits and human beneficiaries is particularly challenging when the responsibility for promoting different ES is divided between multiple government agencies or conservation organizations. For example, the U.S. Fish and Wildlife Service (USFWS) seeks to ensure protection of Federal Trust Species, whereas the Environmental Protection Agency (EPA) is charged with reducing pollution. There are few incentives for these agencies to work collaboratively to manage landscapes for multiple benefits, and it remains unclear what trade-offs exist, what value-added opportunities are being missed, and what policies or programs can be developed to promote greater efficiency. A further challenge is that agencies are largely focused on meeting biophysical standards related to their management goals and do not always consider how these environmental changes affect human well-being or impact they have on other agency goals. For example, compliance with the Clean Water Act requires monitoring and assessment of water quality in the U.S., but monitoring programs do not necessarily consider how changes in pollutant loads have an impact on the health, recreation opportunities, or livelihoods of residents, nor do they consider the consequences to a broader suite of benefits. Ignoring spatial heterogeneity in the demand for multiple ES means that public agency investments are unlikely to be delivering the greatest public benefits at the lowest cost. In addition, the current compartmentalized approach to managing ES has the potential to result in the duplication of efforts and missed opportunities for maximizing total benefits while pursuing a single objective. An ES approach addresses this challenge by serving as a framework for balancing trade-offs and prioritizing mutually beneficial actions of organizations with diverse missions (Galler et al. 2016).

However, there remains a gap between theory and practice and few examples of how an ES approach differs from business-as- 
usual. This gap is evident in our review of statutory language and targeting metrics used by state programs in Minnesota. Similar to the best practices for integrating ecosystem services into federal decisions outlined by Olander et al. (2015), we were looking for evidence of benefit relevant indicators that link the provision of multiple ecosystem services (e.g., changes in water quality) with metrics relevant to specific human endpoints (e.g., drinking water quality). Even with state laws that emphasize multiple benefits and human endpoints, we found that most publicly funded Minnesota land conservation programs are focused on a limited set of benefits, mostly habitat-based metrics, and few use benefitrelevant indicators to prioritize investments. This gap is especially apparent for water quality services, in which the only two programs using water quality metrics to prioritize investments do not weight them more than $5 \%$ of the total score.

This pattern may in part be explained by the funding structures in Minnesota state government. Funding mechanisms enabled by the state constitution (i.e., Environmental and Natural Resources Trust Fund, and the Clean Water, Land, and Legacy Amendment), have a clear mandate to target multiple services and provide benefits to Minnesota residents. However, large portions of these funds are distributed to the state agency programs reviewed, which may not have clear direction on multiple benefits or human well-being in their enabling legislation (Table 1). The statutory emphasis on habitat, recreation, and water may be the result of the high level at which legislation is written. Legislators are not experts in ES or conservation science, and these three terms encompass environmental benefits for many. Statutes passed by legislators are implemented by agencies staffed by resource professionals, many of whom know the importance of ES. However, as Presnall et al. (2015) demonstrated, many practitioners will not implement an ES approach unless it is an explicit requirement.

\section{Limitations of the study that may affect interpretation of findings}

The quantitative metrics we reviewed do not fully capture the decision-making process used by conservation organizations to set priorities and identify opportunities. In addition to these metrics, many programs rely on expert opinion, insights from field staff, and landowner submissions to determine which parcels are considered. Local expertise can aid in identifying conservation opportunities that are likely to be successful or will generate significant value. This expertise is not easy to represent in generalizable metrics that can be applied to all locations.

We do not capture the implicit weight that programs such as the BWSR's Wildlife Riparian Buffers and Grassland Reserve place on water quality through their existence. Previous research has suggested that targeting habitat can result in protection of multiple benefits (Polasky et al. 2012), however, our study did not assess the outcomes achieved by the acquisitions of the programs reviewed, only the scoring systems. The activities performed by these programs are likely beneficial to water quality, however, the scoring systems employed did not predict the magnitude of change in pollutants such as nitrogen or phosphorus relative to other potential acquisitions.

It is also challenging to isolate the weight attributed to the broader service categories required to make the comparisons between organizations. Metrics related to recreation potential are especially difficult because of their overlap with habitat and water quality related metrics. The size of a parcel and the presence of nearby natural features, opportunities for hunting or wildlife viewing, and the clarity of water bodies all contribute to the recreational value of a parcel but are not included in this category. The intertwined nature of services highlights both the potential for providing multiple public benefits with a single investment and the difficulty of managing those services and communicating the value of these public investments in terms of the specific services they provide and to whom.

\section{Recommendations for ecosystem services researchers}

Broad citizen support for conservation, legal authority, public funding, and the availability of comprehensive spatial environmental data make Minnesota well-positioned to emerge as a national leader in state efforts to implement an ES approach. However, current approaches to land conservation and prioritization are still heavily biased toward habitat protection, lack consideration of a broad suite of public benefits, and do not sufficiently link ecosystem service flows and human well-being. Ecosystem services researchers can address these gaps through the development of metrics that capture the value of ES to households and communities.

Simple metrics such as slope, erodibility, and proximity to waterways miss the nuances of where, why, and how much people care about water quality (Keeler et al. 2012). Metrics must take into account the spatial relationship between where an ecological function is performed, and where it ultimately benefits humans to fully implement and prioritize based on an ES approach (Tallis and Polasky 2009). Accounting for spatial links between the production of ES and beneficiaries is particularly relevant for programs that acquire easements that do not allow for public access to the parcel itself. In this case, considering the accessibility of benefits requires identifying public benefits that are influenced by the management practices on a private parcel, such as reduced sedimentation in public waters used for recreation, or whether or not it is visible from a public park.

Refining research on beneficiaries will allow policy makers and practitioners to target the land that maximizes human well-being instead of ecological function. The research community must also do more to make these methodologies and associated datasets accessible to practitioners, policy makers, and the public (Sitas et al. 2014). Olander et al. (2017) suggest that researchers who are focused on publishing novel and increasingly precise methodologies often produce tools that are too complicated to run or are not suited for the decision contexts practitioners must contend with.

Research, which will better identify land that is both ecologically valuable and at risk of development or degradation due to invasive species, climate change, or other threats, is also needed. Current efforts to prioritize based on risk of development or other threats are typically based on expert opinion and are not heavily weighted (Fig. 1). Improving the quality of these predictions will improve a program's ability to protect the most vulnerable lands in addition to the most valuable lands for supplying ES.

\section{Recommendations for policy makers and practitioners}

Minnesota statutes already enable an ecosystem services based approach, but does not provide guidance to define and prioritize 
among competing objectives. Similarly, the guidance on considering human beneficiaries is never more specific than "residents of Minnesota." Examples of formulas exist within Minnesota statutes to promote the equitable distribution of resources for parks and trails to regions of the state based on factors such as local population and quantity of nonlocal visitors (Minnesota Statutes 2017 section 85.53 subdivision 3; ORS 2017). Similar approaches could be used to ensure that other environmental benefits are equitably distributed. Those managing state conservation funds could do more to advocate for the adoption of ES approaches by more explicitly linking the ES objectives in their enabling statute to the requirements for receiving public funds. This would create greater incentives for cross-agency collaboration, data sharing, and a more comprehensive approach to prioritizing the multiple benefits of land conservation investments.

Recent studies on the efficacy of ES approaches in policy have shown that capacity to perform assessments is often a limiting factor, and that being perceived as unbiased is crucial for acceptance (Mckenzie et al. 2014, Sitas et al. 2014, Posner et al. 2016). Policy makers could do more to foster transparency in ecosystem service based decision making by requiring, and providing capacity for, consistent quantitative evaluation of parcels between organizations and programs. Organizations could supplement this analysis with metrics specific to their mission, but a baseline assessment common to all organizations would enable a more rigorous accounting of the public benefits of public investments in conservation. Analyzing and publishing consistent quantitative data on all proposed acquisitions would help programs communicate the value of their work in terms of direct benefits to people and better justify the selection of parcels that best represent the public interest. Another key element for successful implementation of an ES approach, identified by Olander et al. (2017) and called for in the IPBES framework, is the codevelopment of ES knowledge and conservation priorities and interventions in partnership with stakeholders, landowners, restoration professionals, and implementing agencies (Cash et al. 2003, Tengö et al. 2014, Díaz et al. 2015).

Given the prominence of water quality in Minnesota statutes, practitioners' current emphasis on metrics related to habitat quality stands in contrast to the absence of metrics devoted to water quality. Current prioritization systems may exclude inexpensive and ecologically beneficial parcels in their quest for the highest quality habitat. Recent advances in science, technology, and data acquisition have enabled analysts to better capture the complex processes that make up multiple ecological production functions as well as the human demand for ecosystem services. Many of the programs reviewed could better target human well-being objectives by using, or more substantially weighting, readily available, detailed, and reliable census data. Furthermore, use of metrics such as the EPA's vulnerability indicators (US EPA 2016) could help to prevent and correct environmental justice issues in conservation acquisitions.

\section{Implications for global conservation efforts}

Although the focus of our analysis was on implementation of an ES approach in conservation programs in a single U.S. state, our observations on the difficulty of implementing an ES approach are relevant for other regions as well as for conservation efforts at national and international levels. At the international level, IPBES and other global initiatives, such as the Bonn Challenge for forest landscape restoration and the United Nations World Ocean Assessment, are investigating how best to protect and restore ecosystems so that they continue to provide ES (Díaz et al. 2015, Chazdon et al. 2017, United Nations 2017). In making recommendations about conservation investments, IPBES and the implementing partners at the national and subnational levels will need to provide guidance on how to institutionalize and mainstream an ES approach that balances trade-offs between multiple objectives and aims to enhance human well-being and biodiversity protection. As demonstrated in Minnesota, clear statutory guidance to target multiple benefits and human wellbeing does not always translate to implementation. Conservation organizations and programs with roots in biodiversity and habitat protection continue to choose metrics on habitat quality over ecosystem-service based metrics that more explicitly connect to human well-being. The recommendations we outline also have relevance to these international initiatives as leaders and implementing partners debate how to best mainstream ES approaches into guidance and decision making at multiple scales.

\section{CONCLUSION}

The decision-making process used to prioritize investments in conservation easements and acquisitions in Minnesota is not directly targeting multiple benefits or maximizing benefits to humans, despite the legal authority to adopt these elements of an ES approach. With current advances in science and data collection, practitioners have the data and supporting science to target investments that not only maximize the return from multiple ES, but also to account for benefits in terms that are directly relevant to human well-being. The legal framework for this approach already exists in Minnesota statutes, but further collaboration between conservation organizations and increased capacity for ES analysis will be required to leverage current and future ES science advances and codeveloped decision-making processes to maximize returns to human well-being from investments in conservation.

Responses to this article can be read online at: http://www.ecologyandsociety.org/issues/responses. $\mathrm{php} / 9581$

\section{Acknowledgments:}

This work was funded by a grant from the Legislative-Citizen Commission on Minnesota Resources (LCCMR): M.L. 2015, Chp. 76, Sec. 2, Subd. 09k.

\section{LITERATURE CITED}

Boyd, J., and S. Banzhaf. 2007. What are ecosystem services? The need for standardized environmental accounting units. Ecological Economics 63(2-3):616-626. http://dx.doi.org/10.1016/j. ecolecon.2007.01.002

Cash, D. W., W. C. Clark, F. Alcock, N. M. Dickson, N. Eckley, D. H. Guston, J. Jäger, and R. B. Mitchell. 2003. Knowledge 
systems for sustainable development. Proceedings of the National Academy of Sciences 100(14):8086-8091. http://dx.doi.org/10.1073/ pnas. 1231332100

Chazdon, R. L., P. H. S. Brancalion, D. Lamb, L. Laestadius, M. Calmon, and C. Kumar. 2017. A policy-driven knowledge agenda for global forest and landscape restoration. Conservation Letters 10(1):125-132. http://dx.doi.org/10.1111/conl.12220

Daily, G. C., S. Polasky, J. Goldstein, P. M. Kareiva, H. A. Mooney, L. Pejchar, T. H. Ricketts, J. Salzman, and R. Shallenberger. 2009. Ecosystem services in decision making: time to deliver. Frontiers in Ecology and the Environment 7(1):21-28. http://dx.doi.org/10.1890/080025

Díaz, S., S. Demissew, J. Carabias, C. Joly, M. Lonsdale, N. Ash, A. Larigauderie, J. R. Adhikari, S. Arico, A. Báldi, A. Bartuska, I. A. Baste, A. Bilgin, E. Brondizio, K. M. A. Chan, V. E. Figueroa, A. Duraiappah, M. Fischer, R. Hill, T. Koetz, P. Leadley, P. Lyver, G. M. Mace, B. Martin-Lopez, M. Okumura, D. Pacheco, U. Pascual, E. S. Pérez, B. Reyers, E. Roth, O. Saito, R. J. Scholes, N. Sharma, H. Tallis, R. Thaman, R. Watson, T. Yahara, Z. A. Hamid, C. Akosim, Y. Al-Hafedh, R. Allahverdiyev, E. Amankwah, T. S. Asah, Z. Asfaw, G. Bartus, L. A. Brooks, J. Caillaux, G. Dalle, D. Darnaedi, A. Driver, G. Erpul, P. EscobarEyzaguirre, P. Failler, A. M. M. Fouda, B. Fu, H. Gundimeda, S. Hashimoto, F. Homer, S. Lavorel, G. Lichtenstein, W. A. Mala, W. Mandivenyi, P. Matczak, C. Mbizvo, M. Mehrdadi, J. P. Metzger, J. B. Mikissa, H. Moller, H. A. Mooney, P. Mumby, H. Nagendra, C. Nesshover, A. A. Oteng-Yeboah, G. Pataki, M. Roué, J. Rubis, M. Schultz, P. Smith, R. Sumaila, K. Takeuchi, S. Thomas, M. Verma, Y. Yeo-Chang, and D. Zlatanova. 2015. The IPBES conceptual framework - connecting nature and people. Current Opinion in Environmental Sustainability 14:1-16. http:// dx.doi.org/10.1016/j.cosust.2014.11.002

Donovan, S., C. Goldfuss, and J. Holdren. 2015. Memorandum for executive departments and agencies. Executive Office of the President, Washington, D.C., USA. [online] URL: https:// obamawhitehouse.archives.gov/sites/default/files/omb/memoranda/2016/ m-16-01.pdf

Galler, C., C. Albert, and C. von Haaren. 2016. From regional environmental planning to implementation: paths and challenges of integrating ecosystem services. Ecosystem Services 18:118-129. http://dx.doi.org/10.1016/j.ecoser.2016.02.031

Guerry, A. D., S. Polasky, J. Lubchenco, R. Chaplin-Kramer, G. C. Daily, R. Griffin, M. Ruckelshaus, I. J. Bateman, A. Duraiappah, T. Elmqvist, M. W. Feldman, C. Folke, J. Hoekstra, P. M. Kareiva, B. L. Keeler, S. Li, E. McKenzie, Z. Ouyang, B. Reyers, T. H. Ricketts, J. Rockström, H. Tallis, and B. Vira. 2015. Natural capital and ecosystem services informing decisions: from promise to practice. Proceedings of the National Academy of Sciences 112(24):7348-7355. http://dx.doi.org/10.1073/pnas.1503751112

Keeler, B. L., S. Polasky, K. A. Brauman, K. A. Johnson, J. C. Finlay, A. O’Neill, K. Kovacs, and B. Dalzell. 2012. Linking water quality and well-being for improved assessment and valuation of ecosystem services. Proceedings of the National Academy of Sciences 109(45):18619-18624. http://dx.doi.org/10.1073/pnas.1215991109

Kupers, R., M. Gough, M. Lok, F. Saldanha, and R. Spencer. 2015. Enabling business decisions that integrate natural capital: learning from a complex systems perspective. Natural Capital Coalition, London, UK. [online] URL: http://naturalcapitalcoalition. org/wp-content/uploads/2016/08/019750_NCC_White_Paper_Draft29. pdf

Landers, D. H., and A. M. Nahlik. 2013. Final ecosystem goods and services classification system (FEGS-CS). U.S. Environmental Protection Agency, Office of Research and Development, Washington, D.C., USA. [online] URL: https://cfpub.epa.gov/si/ si public record report.cfm?dirEntryId $=257922$

Legislative Coordinating Commission (LCC). 2016a. Appropriations - Minnesota's Legacy. Minnesota Legislature, St. Paul, Minnesota, USA. [online] URL: http://www.legacy.leg.mn/ appropriations

Legislative Coordinating Commission (LCC). 2016b. Trust fund appropriations - Minnesota's Legacy. Minnesota Legislature, St. Paul, Minnesota, USA. [online] URL: http://www.legacy.leg.mn/ appropriations

Liu, J., S. Li, Z. Ouyang, C. Tam, and X. Chen. 2008. Ecological and socioeconomic effects of China's policies for ecosystem services. Proceedings of the National Academy of Sciences 105 (28):9477-9482. http://dx.doi.org/10.1073/pnas.0706436105

Mckenzie, E., S. Posner, P. Tillmann, J. R. Bernhardt, K. Howard, and A. Rosenthal. 2014. Understanding the use of ecosystem service knowledge in decision making: lessons from international experiences of spatial planning. Environment and Planning $C$ : Government and Policy 32(2):320-340. http://dx.doi.org/10.1068/ c12292j

Millennium Ecosystem Assessment (MEA). 2005. Ecosystems and human well-being: synthesis. Island, Washington, D.C., USA. [online] URL: https://www.millenniumassessment.org/documents/ document.356.aspx.pdf

Office of the Revisor of Statutes (ORS). 1998. Constitution of the state of Minnesota Article XI Section 14. Office of the Revisor of Statutes, St. Paul, Minnesota, USA. [online] URL: https://www. revisor.mn.gov/constitution/

Office of the Revisor of Statutes (ORS). 2008. Constitution of the state of Minnesota Article XI Section 15. Office of the Revisor of Statutes, St. Paul, Minnesota, USA. [online] URL: https://www. revisor.mn.gov/constitution/

Office of the Revisor of Statutes (ORS). 2017. 2017 Minnesota statutes section 86A.05 subdivision 8. Office of the Revisor of Statutes, St. Paul, Minnesota, USA. [online] URL: https://www. revisor.mn.gov/statutes/?id=86a.05

Office of the Revisor of Statutes (ORS). 2017. 2017 Minnesota statutes 85.53 subdivision 3. Office of the Revisor of Statutes, St. Paul, Minnesota, USA. [online] URL: https://www.revisor.mn. gov/statutes/?id=85.53

Olander, L., R. J. Johnston, H. Tallis, J. Kagan, L. Maguire, S. Polasky, D. Urban, J. Boyd, L. Wainger, and M. Palmer. 2015. Best practices for integrating ecosystem services into federal decision making. National Ecosystem Services Partnership, Duke University, Durham, North Carolina, USA. [online] URL: https://nicholasinstitute.duke.edu/sites/default/files/publications/ es best practices fullpdf $0 . p d f$ 
Olander, L., S. Polasky, J. S. Kagan, R. J. Johnston, L. Wainger, D. Saah, L. Maguire, J. Boyd, and D. Yoskowitz. 2017. So you want your research to be relevant? Building the bridge between ecosystem services research and practice. Ecosystem Services 26:170-182. http://dx.doi.org/10.1016/j.ecoser.2017.06.003

Ouyang, Z., H. Zheng, Y. Xiao, S. Polasky, J. Liu, W. Xu, Q. Wang, L. Zhang, Y. Xiao, E. Rao, L. Jiang, F. Lu, X. Wang, G. Yang, S. Gong, B. Wu, Y. Zeng, W. Yang, and G. C. Daily. 2016. Improvements in ecosystem services from investments in natural capital. Science 352(6292):1455-1459. http://dx.doi.org/10.1126/ $\underline{\text { science.aaf } 2295}$

Pagiola, S. 2008. Payments for environmental services in Costa Rica. Ecological Economics 65(4):712-724. http://dx.doi. org/10.1016/j.ecolecon.2007.07.033

Polasky, S., K. Johnson, B. Keeler, K. Kovacs, E. Nelson, D. Pennington, A. J. Plantinga, and J. Withey. 2012. Are investments to promote biodiversity conservation and ecosystem services aligned? Oxford Review of Economic Policy 28(1):139-163. http:// dx.doi.org/10.1093/oxrep/grs011

Posner, S. M., E. McKenzie, and T. H. Ricketts. 2016. Policy impacts of ecosystem services knowledge. Proceedings of the National Academy of Sciences 113(7):1760-1765. http://dx.doi. org/10.1073/pnas. 1502452113

Presnall, C., L. López-Hoffman, and M. L. Miller. 2015. Adding ecosystem services to environmental impact analyses: more sequins on a "bloated Elvis" or rockin' idea? Ecological Economics 115:29-38. http://dx.doi.org/10.1016/j.ecolecon.2014.02.001

Schaefer, M., E. Goldman, A. M. Bartuska, A. Sutton-Grier, and J. Lubchenco. 2015. Nature as capital: advancing and incorporating ecosystem services in United States federal policies and programs. Proceedings of the National Academy of Sciences 112(24):7383-7389. http://dx.doi.org/10.1073/pnas.1420500112

Sitas, N., H. E. Prozesky, K. J. Esler, and B. Reyers. 2014. Opportunities and challenges for mainstreaming ecosystem services in development planning: perspectives from a landscape level. Landscape Ecology 29:1315-1331. https://doi.org/10.1007/ $\underline{\text { s10980-013-9952-3 }}$

Tallis, H., and S. Polasky. 2009. Mapping and valuing ecosystem services as an approach for conservation and natural-resource management. Annals of the New York Academy of Sciences 1162:265-283. http://dx.doi.org/10.1111/j.1749-6632.2009.04152. $\underline{\mathrm{x}}$

Tengö, M., E. S. Brondizio, T. Elmqvist, P. Malmer, and M. Spierenburg. 2014. Connecting diverse knowledge systems for enhanced ecosystem governance: the multiple evidence base approach. Ambio 43(5):579-591. https://doi.org/10.1007/ $\underline{\text { s13280-014-0501-3 }}$

The Economics of Ecosystems and Biodiversity (TEEB). 2010. Mainstreaming the economics of Nature: a synthesis of the approach, conclusions and recommendations of TEEB. TEEB, Geneva, Switzerland. [online] URL: http://www.teebweb.org/ publication/mainstreaming-the-economics-of-nature-a-synthesisof-the-approach-conclusions-and-recommendations-of-teeb/
U.S. Environmental Protection Agency (US EPA). 2016. EJSCREEN environmental justice mapping and screening tool: EJSCREEN technical documentation. U.S. Environmental Protection Agency, Washington, D.C., USA. [online] URL: https://19january2017snapshot.epa.gov/sites/production/files/2016-07/ documents/ejscreen_technical_document_20160704_draft.pdf

UK National Ecosystem Assessment (UK NEA). 2014. The UK national ecosystem assessment: follow-on: synthesis of the key findings. UK National Ecosystem Assessment, Cambridge, UK. [online] URL: http://uknea.unep-wcmc.org/Resources/tabid/82/ Default.aspx

United Nations. 2017. United Nations world ocean assessment. United Nations, New York, New York, USA. [online] URL: http://www.worldoceanassessment.org/ 
Appendix 1. Review of statutory language of conservation acquisition programs and conservation funds in Minnesota for principles of ecosystem services.

Table A1.1. Citations from Minnesota statute that support principles of ecosystem services in the conservation activities that they provide guidance for or enable. The text that was used to make the determination of presence of ecosystem services principles is available below this table. This is not an exhaustive list of statutory text that meets the ecosystem services principles criteria.

\begin{tabular}{|c|c|c|}
\hline Program & $\begin{array}{c}\text { Directly calls for multiple } \\
\text { benefits, or lists several benefits? }\end{array}$ & $\begin{array}{c}\text { Directly calls for humans as } \\
\text { beneficiaries? }\end{array}$ \\
\hline $\begin{array}{l}\text { DNR Aquatic Management } \\
\text { Areas }\end{array}$ & $\begin{array}{l}\text { 86A.05 Subd. } 14 \text { (a), (b) } \\
\text { 97C.02 }\end{array}$ & 97C.02 \\
\hline $\begin{array}{l}\text { DNR Wildlife Management } \\
\text { Areas }\end{array}$ & 86A.05 Subd. 8. (a), (b) & 97A.135 Subd. 1. (a) \\
\hline $\begin{array}{l}\text { DNR Trout Stream } \\
\text { Easements }\end{array}$ & 84.0272 Subd. 2. (a) & 84.0272 Subd. 2. (a) \\
\hline $\begin{array}{l}\text { DNR Scientific and Natural } \\
\text { Areas }\end{array}$ & $\begin{array}{l}\text { 84.944 Subd. 1. (a) } \\
\text { 86A.05 Subd. } 5 .\end{array}$ & 86A.05 Subd. 5. (e) \\
\hline DNR Native Prairie Bank & No & No \\
\hline DNR Forests for the Future & $\begin{array}{l}\text { 84.66 Subd. 1-5. } \\
89.001 \text { Subd. } 8\end{array}$ & $\begin{array}{l}\text { 84.66 Subd. } 3 . \\
\text { 84.66 Subd. } 6 . \\
\text { 89.001 Subd. } 8 .\end{array}$ \\
\hline $\begin{array}{l}\text { Reinvest in Minnesota } \\
\text { Resources (RIM) }\end{array}$ & $\begin{array}{l}\text { 103F.505 } \\
\text { 103F.515 Subd. } 1 .\end{array}$ & Not directly \\
\hline $\begin{array}{l}\text { Environment and Natural } \\
\text { Resources Trust Fund }\end{array}$ & 116P.08 Subd. 1. (6) & 116P.01 \\
\hline Clean Water Fund & 114D.50 Subd. 4. (a) & $\begin{array}{l}\text { 114D.10 Subd. 2. (1) } \\
\text { 114D.50 Subd. 4. (b) } \\
\text { 114D.50 Subd. 4. (e) }\end{array}$ \\
\hline Outdoor Heritage Fund & $\begin{array}{l}\text { 97A.056 Subd. (1) } \\
\text { 97A.056 Subd. (3) (a), (c) }\end{array}$ & 97A.056 Subd. 19. (a) \\
\hline
\end{tabular}




\section{Department of Natural Resources- Aquatic Management Area}

\section{Received Environment and Natural Resources Trust Fund funding: Yes \\ Received Outdoor Heritage Fund funding: Yes Received Clean Water Fund funding: No}

\section{Language relating to multiple benefits:}

97C.02 The commissioner shall acquire lands that are critical for fish and other aquatic life and that meet criteria described for aquatic management areas in section 86A.05, subdivision 14 . The lands that are acquired may be developed to manage lakes, rivers, streams, and adjacent wetlands and lands for aquatic life, water quality, intrinsic biological value, public fishing, and other compatible outdoor recreational uses. The land may be acquired by gift, lease, easement, or purchase. The commissioner shall designate land acquired under this subdivision as aquatic management areas for the purposes of the outdoor recreation system.

86A.05 Subd. 14. Aquatic management areas.

(a) Aquatic management areas may be established to protect, develop, and manage lakes, rivers, streams, and adjacent wetlands and lands that are critical for fish and other aquatic life, for water quality, and for their intrinsic biological value, public fishing, or other compatible outdoor recreational uses.

(b) Aquatic management areas may be established to protect wetland areas under ten acres that are donated to the Department of Natural Resources.

(c) No unit may be authorized unless it meets one or more of the following criteria:

(1) provides angler or management access;

(2) protects fish spawning, rearing, or other unique habitat;

(3) protects aquatic wildlife feeding and nesting areas;

(4) protects critical shoreline habitat; or

(5) provides a site for research on natural history.

(d) Aquatic management areas must be administered by the commissioner of natural resources in a manner consistent with the purposes of this subdivision to perpetuate and, if necessary, reestablish high quality aquatic habitat for production of fish, wildlife, and other aquatic species. Public fishing and other uses shall be consistent with the limitations of the resource, including the need to preserve adequate populations and prevent longterm habitat injury or excessive fish population reduction or increase. Public access to aquatic management areas may be closed during certain time periods.

\section{Language relating to human beneficiaries:}

97C.02 The commissioner shall acquire lands that are critical for fish and other aquatic life and that meet criteria described for aquatic management areas in section 86A.05, subdivision 14. The lands that are acquired may be developed to manage lakes, rivers, streams, and adjacent wetlands and lands for aquatic life, water quality, intrinsic biological value, public fishing, and other compatible outdoor recreational uses. The land may be acquired by gift, lease, easement, or purchase. The commissioner shall designate land acquired under this subdivision as aquatic management areas for the purposes of the outdoor recreation system. 


\section{Department of Natural Resources- Wildlife Management Area}

\section{Received Environment and Natural Resources Trust Fund funding: Yes \\ Received Outdoor Heritage Fund funding: Yes \\ Received Clean Water Fund funding: No}

\section{Language relating to multiple benefits:}

86A.05 Subd. 8. State wildlife management area; purpose; resource and site qualifications; administration.

(a) A state wildlife management area shall be established to protect those lands and waters which have a high potential for wildlife production and to develop and manage these lands and waters for the production of wildlife, for public hunting, fishing, and trapping, and for other compatible outdoor recreational uses.

(b) No unit shall be authorized as a state wildlife management area unless its proposed location substantially satisfies the following criteria:

(1) includes appropriate wildlife lands and habitat, including but not limited to marsh or wetlands and the margins thereof, ponds, lakes, stream bottomlands, and uplands, which permit the propagation and management of a substantial population of the desired wildlife species; and

(2) includes an area large enough to ensure adequate wildlife management and regulation of the permitted recreational uses.

\section{Language relating to human beneficiaries:}

97A.135 Subd. 1. (a) The commissioner or the commissioner of administration shall acquire and improve land for public hunting, game refuges, and food and cover planting. The land may be acquired by a gift, lease, easement, purchase, or condemnation. At least two-thirds of the total area acquired in a county must be open to public hunting.

\section{Department of Natural Resources- Trout Stream Easements}

\section{Received Environment and Natural Resources Trust Fund funding: Yes Received Outdoor Heritage Fund funding: Yes Received Clean Water Fund funding: No}

\section{Language relating to multiple benefits:}

84.0272 Subd. 2. (a) Notwithstanding subdivision 1, the commissioner may acquire permanent stream easements for angler access, fish management, and habitat work for a onetime payment based on a value attributed to both the stream and the easement corridor. The payment shall equal:

\section{Language relating to human beneficiaries:}

84.0272 Subd. 2. (a) Notwithstanding subdivision 1, the commissioner may acquire permanent stream easements for angler access, fish management, and habitat work for a onetime payment based on a value attributed to both the stream and the easement corridor. The payment shall equal: 


\section{Department of Natural Resources- Native Prairie Bank}

\section{Received Environment and Natural Resources Trust Fund funding: Yes \\ Received Outdoor Heritage Fund funding: Yes \\ Received Clean Water Fund funding: No}

\section{Language relating to multiple benefits:}

The statute is silent with regards to the criteria used to prioritize acquisition, but grants the authority to prescribe eligibility requirements to the commissioner of natural resources. Without more specific guidance, the enabling legislation for the native prairie bank program does not meet the multiple benefits criterion.

84.96 Subd. 1. The commissioner shall establish a native prairie bank, determine where native prairie land is located in the state, and prescribe eligibility requirements for inclusion of land in the native prairie bank.

\section{Language relating to human beneficiaries:}

None

\section{Department of Natural Resources- Scientific and Natural Areas}

\section{Received Environment and Natural Resources Trust Fund funding: Yes \\ Received Outdoor Heritage Fund funding: Yes \\ Received Clean Water Fund funding: No}

\section{Language relating to multiple benefits:}

84.944 Subd. 1. (a) In determining what critical natural habitat shall be acquired or improved, the commissioner shall consider:

(1) the significance of the land or water as existing or potential habitat for fish and wildlife and providing fish and wildlife oriented recreation;

(2) the significance of the land, water, or habitat improvement to maintain or enhance native plant, fish, or wildlife species designated as endangered or threatened under section 84.0895;

(3) the presence of native ecological communities that are now uncommon or diminishing; and

(4) the significance of the land, water or habitat improvement to protect or enhance natural features within or contiguous to natural areas including fish spawning areas, wildlife management areas, scientific and natural areas, riparian habitat and fish and wildlife management projects.

(b) Based on the above clauses, the commissioner by rule must establish a process to prioritize what critical habitat shall be acquired or improved.

86A.05 Subd. 5. State scientific and natural areas; purpose; resource and site qualifications; administration; designation. 
(a) A state scientific and natural area shall be established to protect and perpetuate in an undisturbed natural state those natural features which possess exceptional scientific or educational value.

(b) No unit shall be authorized as a scientific and natural area unless its proposed location substantially satisfies the following criteria:

(1) embraces natural features of exceptional scientific and educational value, including but not limited to any of the following:

(i) natural formations or features which significantly illustrate geological processes;

(ii) significant fossil evidence of the development of life on earth;

(iii) an undisturbed plant community maintaining itself under prevailing natural conditions typical of Minnesota;

(iv) an ecological community significantly illustrating the process of succession and restoration to natural condition following disruptive change;

(v) a habitat supporting a vanishing, rare, endangered, or restricted species of plant or animal;

(vi) a relict flora or fauna persisting from an earlier period; or

(vii) a seasonal haven for concentrations of birds and animals, or a vantage point for

observing concentrated populations, such as a constricted migration route; and

(2) embraces an area large enough to permit effective research or educational functions and to preserve the inherent natural values of the area.

(c) State scientific and natural areas shall be administered by the commissioner of natural resources, in consultation with qualified persons, in a manner which is consistent with the purposes of this subdivision to preserve, perpetuate and protect from unnatural influences the scientific and educational resources within them. Interpretive studies may be provided for the general public. Physical development shall be limited to the facilities absolutely necessary for protection, research, and educational projects, and, where appropriate, for interpretive services.

\title{
Language relating to human beneficiaries:
}

86A.05 Subd. 5. (e) At the discretion of the managing agency, each scientific and natural area shall be designated as one of the following types:

(i) Research unit. Use is limited to programs conducted by qualified scientists and college graduate and postgraduate students.

(ii) Educational unit. Permitted uses include all activities specified in paragraph (i) above and primary, secondary, and college undergraduate programs.

(iii) Public use unit. Permitted uses include all uses permitted in paragraphs (i) and (ii) above and interpretive programs for the benefit of the general public.

\section{Department of Natural Resources- Forests for the Future}

\author{
Received Environment and Natural Resources Trust Fund funding: No \\ Received Outdoor Heritage Fund funding: Yes \\ Received Clean Water Fund funding: No
}




\section{Language relating to multiple benefits:}

84.66 Subd. 1. The Minnesota forests for the future program identifies and protects private, working forest lands for their timber, scenic, recreational, fish and wildlife habitat, threatened and endangered species, and other cultural and environmental values.

84.66 Subd. 2. (5) "working forest land" means land that provides a broad range of goods and services, including forest products, recreation, fish and wildlife habitat, clean air and water, and carbon sequestration.

84.66 Subd. 3. The commissioner of natural resources shall establish and administer a Minnesota forests for the future program. Land selected for inclusion in the program shall be evaluated on the land's potential for:

(1) producing timber and other forest products;

(2) maintaining forest landscapes;

(3) providing public recreation; and

(4) providing ecological, fish and wildlife habitat, and other cultural and environmental values and values consistent with working forest lands.

84.66 Subd. 4. Land may be placed in the Minnesota forests for the future program if it: (1) is:

(i) forest land;

(ii) desirable land adjacent to forest land, as determined by the commissioner; or

(iii) beneficial to forest resource* protection;

(2) is at least five acres in size, except for a riparian area or an area providing access to state forest land;

(3) is not set aside, enrolled, or diverted under another federal or state program, unless enrollment in the Minnesota forests for the future program would provide additional conservation benefits or a longer enrollment term than under the current federal or state program.

*89.001 Subd. 8 "Forest resources" means those natural assets of forest lands, including timber and other forest crops; biological diversity; recreation; fish and wildlife habitat; wilderness; rare and distinctive flora and fauna; air; water; soil; climate; and educational, aesthetic, and historic values.

\section{Language relating to human beneficiaries:}

84.66 Subd. 3. The commissioner of natural resources shall establish and administer a Minnesota forests for the future program. Land selected for inclusion in the program shall be evaluated on the land's potential for:

(1) producing timber and other forest products;

(2) maintaining forest landscapes;

(3) providing public recreation; and

(4) providing ecological, fish and wildlife habitat, and other cultural and environmental values and values consistent with working forest lands. 
84.66 Subd. 6. The commissioner shall accept applications from owners of eligible lands at the time, in the form, and containing the information as the commissioner may prescribe. If the number of applications exceeds the ability to fund them all, priority shall be given to those applications covering lands providing the greatest public benefits for timber productivity, public access, and ecological and wildlife values.

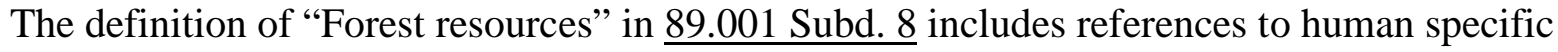
services such as timber, cultural, historic, educational, and aesthetic.

\section{Board of Water and Soil Resources - Reinvest in Minnesota (RIM)}

RIM operates several easement acquisition programs with slightly different scoring systems. The legal authority for the acquisitions all comes from the RIM law, but differences in prioritization arise from different funding sources and management activities. All programs may receive funding from the three funds reviewed here, but Clean Water Fund money is preferentially available for Wildlife Riparian Buffers and acquisitions in wellhead protection areas.

Received Environment and Natural Resources Trust Fund funding: Yes

Received Outdoor Heritage Fund funding: Yes

Received Clean Water Fund funding: Yes

\section{Language relating to multiple benefits:}

$\underline{103 F .505}$ It is the purpose of sections 103F.505 to 103F.531 to restore certain marginal agricultural land and protect environmentally sensitive areas to enhance soil and water quality, minimize damage to flood-prone areas, sequester carbon, and support native plant, fish, and wildlife habitats.

103F.515 Subd. 1. Selection of land for the reinvest in Minnesota reserve program must be based on its enhancement potential for fish, wildlife, and native plant habitats, reducing erosion, and protecting water quality.

\section{Language relating to human beneficiaries:}

No explicit references, but direction to prioritize the protection of drinking water.

103F.515 Subd. 2. (d) Land is eligible if the land is a wellhead protection area as defined under section 103I.005, subdivision 24, and has a wellhead protection plan approved by the commissioner of health.

\section{Environment and Natural Resources Trust Fund}

\section{Language relating to multiple benefits:}

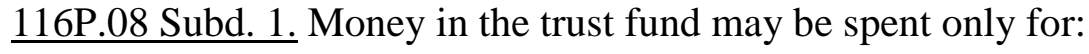


(6) activities that preserve or enhance fish, wildlife, land, air, water, and other natural resources that otherwise may be substantially impaired or destroyed in any area of the state;

Language relating to human beneficiaries:

116P.01 The legislature finds that all Minnesotans share the responsibility to ensure wise stewardship of the state's environment and natural resources for the benefit of current citizens and future generations. Proper management of the state's environment and natural resources includes and requires foresight, planning, and long-term activities that allow the state to preserve its high quality environment and provides for wise use of its natural resources. The legislature also finds that to undertake such activities properly, a long-term, consistent, and stable source of funding must be provided.

\section{$\underline{\text { Clean Water Fund }}$}

\section{Language relating to multiple benefits:}

114D.50 Subd. 4. (a) A project receiving funding from the clean water fund must meet or exceed the constitutional requirements to protect, enhance, and restore water quality in lakes, rivers, and streams and to protect groundwater and drinking water from degradation. Priority may be given to projects that meet more than one of these requirements.

\section{Language relating to human beneficiaries:}

114D.10 Subd. 2. (1) there is a close link between protecting, enhancing, and restoring the quality of Minnesota's groundwater and surface waters and the ability to develop the state's economy, enhance its quality of life, and protect its human and natural resources;

114D.50 Subd. 4 (b) Money from the clean water fund shall be expended to balance the benefits across all regions and residents of the state.

114D.50 Subd. 4 (e) Money from the clean water fund may only be spent on projects that benefit Minnesota waters.

\section{Outdoor Heritage Fund}

\section{Language relating to multiple benefits:}

97A.056 Subd 1. An outdoor heritage fund, under article XI, section 15, of the Minnesota Constitution, is established as an account in the state treasury. All money earned by the outdoor heritage fund must be credited to the fund. At least 99 percent of the money appropriated from the fund must be expended to restore, protect, and enhance wetlands, prairies, forests, and habitat for fish, game, and wildlife. Money appropriated from the outdoor heritage fund shall not be spent to acquire property by eminent domain unless the owner requests that the owner's property be acquired by eminent domain.

97A.056 Subd. 3. (a) The council shall make recommendations to the legislature on appropriations of money from the outdoor heritage fund that are consistent with the Constitution 
and state law and that will achieve the outcomes of existing natural resource plans, including, but not limited to, the Minnesota Statewide Conservation and Preservation Plan, that directly relate to the restoration, protection, and enhancement of wetlands, prairies, forests, and habitat for fish, game, and wildlife, and that prevent forest fragmentation, encourage forest consolidation, and expand restored native prairie. In making recommendations, the council shall consider a range of options that would best restore, protect, and enhance wetlands, prairies, forests, and habitat for fish, game, and wildlife.

(c) The council may work with the Clean Water Council to identify projects that are consistent with both the purpose of the outdoor heritage fund and the purpose of the clean water fund.

\section{Language relating to human beneficiaries:}

97A.056 Subd. 19. (a) Lands acquired by fee with money appropriated from the outdoor heritage fund that are held by the state must be open to the public taking of fish and game during the open season, unless otherwise provided by state law. 
Appendix 2. Weight calculation methods and metric category definitions.

\subsection{Metric category descriptions}

\section{Water quality:}

Metrics related to a parcel's capacity to improve or protect water quality. For example, does the parcel have the capacity to mitigate nutrient or sediment runoff, or does the parcel contributes to a drinking water supply?

\section{Recreation accessibility:}

Metrics related to how easily the public can experience benefits related to this parcel. For example, if it is an easement on private land, is the easement near public hunting land, or is it within the viewshed of a scenic trail? How many people could make a day trip to the area the parcel produces benefits?

\section{Habitat/Biodiversity:}

Metrics that measure the ability or potential ability for a parcel to support species and metrics that identify the presence and/or quality of ecosystems or biodiversity.

\section{Spatial context:}

Metrics that score parcels based on the potential benefits derived from its geographic location. For example, does the parcel contribute to a complex of nearby protected areas, or does it fall in an area identified as part of a planning process (e.g. the Prairie Plan)?

\section{Size:}

Metrics that measure the absolute size of a parcel, or a relative increase in size of a complex.

\section{Risk of development:}

Metrics that prioritize parcels at high risk of development or penalize parcels at low risk.

\section{Management factors:}

Metrics that score a parcel based on the level of management required, or based on the parcel's ability to contribute to the management of an area (e.g. through access).

\section{Donation of portion:}

Metrics that consider if the landowner is willing to donate a portion of the value of the parcel.

Market benefits:

Metrics that consider the value of timber or grazing resources of a parcel.

Public support:

Metrics that measure how much support/engagement there is for an acquisition. 


\subsection{Program scoring weight calculation methodology}

We placed individual metrics used in quantitative scoring systems into ten categories in order to compare the factors that are used to prioritize lands for protection. We created the ten categories to reflect common themes while still encompassing all of the metrics we reviewed. We recognize that a single metric may be relevant to multiple categories; however, to make consistent comparisons between organizations, we assigned each point of a metric to a single category only. We divided the maximum score in a given category by the overall maximum score attainable under each program to determine the weight a program placed on a category.

As an example of our scoring methodology, here is how we calculated the 'Recreation accessibility' score for the DNR Trout Stream Easement program. Of the 17 metrics used in the program, we identified 3 metrics that fell into the 'User accessibility' category because they best capture the value to the public based on how accessible the benefits are to people. The scoring criteria below are from the DNR scoring guidance.

\section{Existing/potential angler use}

$3 \mathrm{pt}=$ based on professional judgement of factors including the stretch's current angler use and demand for additional access.

\section{Accessible}

$1 \mathrm{pt}=$ the proposed easement is crossed by a road or trail that would provide angler access other than from adjoining easement.

\section{Recreation potential}

Points are awarded by GIS tool querying census data for total population within 50 miles.

$0 \mathrm{pt}=<10,000$

$1 \mathrm{pt}=10,001$ to 20,000

$3 \mathrm{pt}=20,001$ to 50,000

$4 \mathrm{pt}=>50,000$

The sum of the maximum scores for each metric is $3+1+4=8$. The maximum amount of points in the scoring system is 48 . Thus, the importance weight of 'User accessibility' is $8 / 48=17 \%$.

The Department of Natural Resources (DNR) Wildlife Management Areas and Aquatic Management Areas programs have slightly different scoring systems depending on where in the state the acquisition is occurring. Having different scores for different regions allows the DNR to better capture the value of certain ecosystems that may be abundant in one part of the state but rare in another, such as forests in the northeast vs. the southwest. After aggregating the metrics into metric categories for this analysis, the regional score differences largely disappeared because the changes often happened in the same category. We report the aggregated values for the 'Transition' region because this region includes the most metrics and is typically within one percentage point of the mean of all regions for a given category (Appendix 3.2).

Some scoring systems had rules that prevented the score of one metric from being reliably isolated. For example, using the Board of Water and Soil Resources (BWSR) Wetland Restoration scoring system, a maximum of 10 points are available for a combination of size and nearby habitat (section B in the tables below), but either metric can achieve 10 points on its own. 
Without a strictly additive score, we could not break this program into categories precisely. We calculated a separate weight for each section of their scoring system based on the number of points theoretically possible and the enforced maximum for each section (Table A2.1). Using the example above, 20 points were available in the section, but only 10 can count toward the final score, thus each point in that section is weighted by 0.5 . Ten of the points fell into the 'Size' category, and after given their section weighting, contribute 5\% of the final score (Table A2.1).

Table A2.1. Determining weights for each section in Board of Water and Soil Resources Wetland Restoration scoring system.

\begin{tabular}{|c|c|c|c|c|c|}
\hline & A & $\mathrm{B}$ & $\mathrm{C}$ & $\mathrm{D}$ & $\mathrm{E}$ \\
\hline Theoretical maximum score & 123 & 20 & 20 & 10 & 15 \\
\hline $\begin{array}{l}\text { Enforced maximum score } \\
\text { Point weight by section }\end{array}$ & 50 & 10 & 20 & 10 & 10 \\
\hline (Enforced / Theoretical) & 0.41 & 0.5 & 1 & 1 & 0.67 \\
\hline
\end{tabular}

Table A2.2. Estimation of weights under the non-additive Board of Water and Soil Resources Wetland Restoration scoring system.

\begin{tabular}{|c|c|c|c|c|c|c|c|c|c|c|c|}
\hline \multirow[b]{2}{*}{ Metric Category } & \multicolumn{5}{|c|}{$\begin{array}{l}\text { Theoretical Maximum } \\
\text { Score by Section }\end{array}$} & \multicolumn{5}{|c|}{ Weighted Maximum Score by Section } & \multirow{2}{*}{$\begin{array}{c}\text { Category } \\
\text { Weight }\end{array}$} \\
\hline & A & $\mathrm{B}$ & $\mathrm{C}$ & $\mathrm{D}$ & $\mathrm{E}$ & A & $\mathrm{B}$ & $\mathrm{C}$ & $\mathrm{D}$ & E & \\
\hline Water quality & & & & & 7 & & & & & 4.67 & 4.67 \\
\hline Recreation accessibility & & & & & & & & & & & 0.00 \\
\hline Habitat/Biodiversity & 83 & & 20 & & 2 & 33.74 & & 20.00 & & 1.33 & 55.07 \\
\hline Spatial context & 10 & 10 & & & 6 & 4.07 & 5.00 & & & 4.00 & 13.07 \\
\hline Size & 30 & 10 & & & & 12.20 & 5.00 & & & & 17.20 \\
\hline Risk of development & & & & & & & & & & & 0.00 \\
\hline Management factors & & & & & & & & & & & 0.00 \\
\hline Donation of portion & & & & 10 & & & & & 10.00 & & 10.00 \\
\hline Market benefits & & & & & & & & & & & 0.00 \\
\hline Public support & & & & & & & & & & & 0.00 \\
\hline
\end{tabular}

In addition to the section-by-section weighting, the BWSR wetlands program posed a challenge in that approximately 33\% it its score is attributed to an inseparable combination of the condition and number/size of depressional wetlands. The scoring system indicated that restorable depressional wetlands were a priority, but did not indicate why. This ambiguity means that 33\% of the score does not fit well into any category, but there was not sufficient evidence to subdivide it. Given the focus on the condition of the wetland we opted to place it into the habitat/biodiversity category, but arguments could be made for size, spatial context, water quality, or a combination of those categories.

Qualitative, expert opinion driven prioritization employed by many smaller and nongovernmental organizations could not be evaluated with this approach, nor could the expert opinion applied in conjunction with quantitative scoring systems. This approach also did not screen for unlikely combinations of attributes when calculating weights. As such, these should be considered an approximation to detect broad trends only. 
Appendix 3. Original program metric language and its classification into metric categories.

Please click here to download file 'appendix 3.xlsx'. 